\title{
Underlying Mechanism of Uncoupled Cell Growth and Ethanol Fermentation of Zymomonas mobilis using Different Nitrogen Sources
}

\section{Runxia Li}

Hubei University

Mingjie Jin

Nanjing University of Science and Technology

Jun Du

China Biotech Fermentation Industry Association

Shouwen Chen

Hubei University

Shihui Yang ( $\nabla$ Shihui.Yang@hubu.edu.cn )

Hubei University https://orcid.org/0000-0002-9394-9148

\section{Research}

Keywords: Zymomonas mobilis, ethanol fermentation, nitrogen sources, yeast extract, metal ions, magnesium, molybdenum, RNA-Seq, stress response

Posted Date: January 24th, 2020

DOI: https://doi.org/10.21203/rs.2.21812/v1

License: (c) (i) This work is licensed under a Creative Commons Attribution 4.0 International License. Read Full License 


\section{Abstract}

Background: Microbial growth needs C, N, P, S as well as metal ions such as magnesium, which is a major cofactor for enzymes involved in various metabolic activities. Yeast extract is widely used as nitrogen supply as well as vitamins and growth factors to sustain microbial growth in the culture medium. Zymomonas mobilis is a model ethanologenic bacterium for ethanol production, and has been developing as a chassis for diverse biochemical production. Although yeast extract is routinely used to prepare rich medium (RM) for $Z$. mobilis, the glucose consumption and ethanol production of $Z$. mobilis in RM were not coupled with cell growth in some studies.

Results: In this study, the effects of different nitrogen sources as well as the supplementation of additional nitrogen source into RM and minimum medium (MM) on cell growth and ethanol fermentation of $Z$. mobilis were investigated to understand the uncoupled cell growth and ethanol fermentation for efficient carbon utilization and optimal ethanol productivity of $Z$. mobilis. Our results indicated that nitrogen sources such as yeast extract from different companies affected cell growth, glucose utilization, and the corresponding ethanol production. We also quantified the concentrations of major ion elements in different organic nitrogen sources using the quantitative analytic approach of Inductively Coupled Plasma Optical Emission Spectroscopy (ICP-OES), and demonstrated that metal ions such as magnesium in the media affected glucose consumption, cell growth, and ethanol fermentation. The effect of magnesium on gene expression was further investigated using RNA-Seq transcriptomics, and our result indicated that the lack of $\mathrm{Mg}^{2+}$ triggered stress responses while decreasing energy-consuming metabolism.

Conclusions: Our work demonstrated that concentrations of metal ions such as magnesium and molybdenum in nitrogen sources are essential for vigorous cell growth, and the difference of $\mathrm{Mg}^{2+}$ concentration in different yeast extract was one of the major factors affecting the coupling of cell growth and ethanol fermentation in $Z$. mobilis. We also revealed that genes responsive for $\mathrm{Mg}^{2+}$ deficiency in the medium were majorly related to stress responses and energy conservation. The importance of metal ions on cell growth and ethanol fermentation suggested that metal ions should become one of the parameters for monitoring the quality of commercial nitrogen sources and optimizing microbial culture medium for economic biochemical production.

\section{Background}

The Gram-negative bacterium Zymomonas mobilis is a natural ethanologen with many desirable industrial biocatalyst characteristics, such as high glucose consumption rate, high specific ethanol productivity, high ethanol tolerance, a broad $\mathrm{pH}$ range for production $(\mathrm{pH} 3.5-7.5)$, and the generally regarded as safe status (GRAS) [1-6]. Compared with Saccharomyces cerevisiae which uses the Embden-Meyerhof-Parnas (EMP) pathway for ethanol production, Z. mobilis has improved ethanol yield by using the Entner-Doudoroff (ED) pathway with $50 \%$ less ATP produced relative to the EMP pathway 
[7-9]. Meanwhile, Z. mobilis utilizes glucose for ethanol production faster than S. cerevisiae because of a high cell surface area, leading to higher ethanol productivity than S. cerevisiae $[3-7,10]$.

Rich medium (RM) containing carbon source such as glucose, nitrogen source such as yeast extract, and $\mathrm{KH}_{2} \mathrm{PO}_{4}$ is commonly used to culture $\mathrm{Z}$. mobilis. Nitrogen source in the medium was reported to affect the growth of Z. mobilis. For example, the morphology of Z. mobilis CP3 changed when cultured in medium with low nitrogen source [11]. Although nitrogen sources like peptone, corn steep liquid, and even $\mathrm{N}_{2}$ can be used to sustain the cell growth of $Z$. mobilis [10-12], yeast extract preserving the $B$ vitamins that naturally occur in yeast is the preferred nitrogen sources.

Yeast extract is the hydrolysate of yeast cells through autolysis or enzymatic hydrolysis, which can provide nitrogenous compounds, carbon, sulfur, trace nutrients, vitamin B complex and other important growth factors for various microorganisms. Despite that the total nitrogen content and free amino acid nitrogen in different yeast extracts are monitored, yeast extracts produced by different companies have different trace components such as growth factors and metal ions due to the differences in their production processes, which will affect the microbial cell growth since the vitamins and metal ions (e.g. $\mathrm{Mg}^{2+}, \mathrm{MoO}_{4}{ }^{2-}, \mathrm{Cu}^{2+}, \mathrm{Zn}^{2+}$, and $\left.\mathrm{Fe}^{2+}\right)$ are cofactors of enzymes involved in various metabolic activities.

Our previous results and literature reports showed that cell growth of ZM4 and its ethanol production were uncoupled in a few studies. Glucose consumption was not coupled with cell growth, and glucose was not completely consumed for ethanol production when cells reached stationary phase [13-19]. This uncoupling phenomenon between growth and fermentation performance has also been reported in other microorganisms including yeast affecting the economic bioproduct production [20,21]. For example, ethanol production of yeast cells was reported to be related to the length of uncoupling phase during the batch fermentation process [22].

The uncoupling of growth and fermentation was majorly due to the stressful physical and chemical growth condition such as extreme temperature, $\mathrm{pH}$ and toxic compounds in the media, limited nutrient sources of carbon, nitrogen and metal ions used for fermentation were also reported to affect cell growth and fermentation performance [19-21,23]. Although the effect of diverse nitrogen sources on cell growth and fermentation performance has been reported in various microorganisms such as the ethanologen yeast and lactate-producer Sporolactobacillus inulinus [24-26], metal ions within nitrogen sources and their impact on cell growth and fermentation has not been investigated extensively with limited information available.

To understand the phenomenon of growth and fermentation uncoupling for both efficient carbon utilization and maximum ethanol productivity, we investigated the effects of different nitrogen sources on the growth and ethanol production of $Z$. mobilis in this study to help achieve the goal of optimal titer, rate, and yield (TRY) for economic bioethanol production using Z. mobilis. Our results demonstrated that glucose consumption and ethanol production can be coupled with cell growth by changing the nitrogen 
sources in the rich medium, and the concentration of metal ions such as $\mathrm{Mg}^{2+}$ and $\mathrm{MoO}_{4}{ }^{2-}$ in the nitrogen source could be one of the major factors affecting cell growth and ethanol production.

\section{Results And Discussions}

\section{Effect of supplementation of nitrogen sources into RM}

To understand the uncoupling of cell growth and ethanol production, we evaluated factors in the medium affecting cell growth. Since the growth condition of $\mathrm{Z}$. mobilis is not complicated, and the recipe of RM is relatively simple containing carbon source such as glucose, phosphate source of $\mathrm{KH}_{2} \mathrm{PO}_{4}$, and yeast extract as the source of nitrogen, minerals and vitamins, $10 \mathrm{mM} \mathrm{NH}_{4} \mathrm{Cl}$ was added into RM using the yeast extract from OXOID (RMOXOID) to increase inorganic nitrogen content. However, extra $\mathrm{NH}_{4} \mathrm{Cl}$ supplemented into $\mathrm{RM}^{\mathrm{OXOID}}$ did not reduce the time for glucose utilization and ethanol production of ZM4 (Data not shown).

The effect of supplementation of different organic nitrogen sources such as peptone and tryptone were then tested. Our results showed that the supplementation of peptone did not reduce the time of glucose utilization. It still took more than 24-h for cells to consume up all glucose in the media with $20 \mathrm{~g} / \mathrm{L}$ peptone supplemented into $\mathrm{RM}^{\mathrm{OXOID}}$, although the final biomass in terms of $\mathrm{OD}_{600}$ value did increased slightly corresponding to the increase of peptone added (Fig. 1).

Subsequently, different concentrations of tryptone were added in RM ${ }^{O X O I D}$. The results showed that the addition of extra tryptone could significantly increase both cell biomass and glucose consumption of ZM4 (Fig. 2). The addition of more than $5 \mathrm{~g} / \mathrm{L}$ tryptone in RM ${ }^{\mathrm{OXOID}}$ can not only enhance both cell growth and glucose utilization of ZM4, but also couple the growth and ethanol fermentation of ZM4. The final highest $\mathrm{OD}_{600}$ value of $Z M 4$ in $\mathrm{RM}^{\mathrm{OXOID}}$ with $5 \mathrm{~g} / \mathrm{L}$ tryptone increased from 1.8 to 4.7 , and all glucose was completed consumed up within $12 \mathrm{~h}$ while the one without tryptone had only half of glucose utilized at the same time point of 12-h post-inoculation (Fig. 2).

The positive effect of adding tryptone into $\mathrm{RM}^{\mathrm{OXOID}}$ was further evaluated by comparing cell growth as well as glucose utilization and ethanol production of $\mathrm{ZM} 4$ in both $\mathrm{RM}^{\mathrm{OXOID}}$ and $\mathrm{RM}^{\mathrm{OXOID}}+5 \mathrm{~T}$ at different temperatures of 30,36 and $40{ }^{\circ} \mathrm{C}$. The results demonstrated that the supplementation of tryptone increased the growth and fermentation performance of ZM4 at different temperatures including the specific growth rate, ethanol yield, and productivity (Table 1). 
Table 1

Ethanol yield $\left(\mathrm{Y}_{\mathrm{p} / \mathrm{s}}\right)$, theoretical ethanol yield $\left(\% \mathrm{Y}_{\mathrm{p} / \mathrm{s}}\right)$, ethanol productivity

$\left(Q_{P}\right)$, and specific growth rate $(\mu)$ of ZM4 in RM ${ }^{\text {OXOID }}$ and RM ${ }^{\text {OXOID }}$

supplemented with $5 \mathrm{~g} / \mathrm{L}$ tryptone at conditions of different temperatures.

\begin{tabular}{|lllll|}
\hline Conditions & $\mathrm{Y}_{\mathrm{p} / \mathrm{s}}$ & $\% \mathrm{Y}_{\mathrm{p} / \mathrm{s}}$ & $\mathrm{Q}_{\mathrm{p}}$ & $\boldsymbol{\mu}$ \\
\hline $30{ }^{\circ} \mathrm{C}, \mathrm{RM}$ OXOID & $0.39 \pm 0.02$ & $76 \pm 4$ & $0.67 \pm 0.03$ & $0.45 \pm 0.01$ \\
\hline $36{ }^{\circ} \mathrm{C}, \mathrm{RM}^{\text {OXOID }}$ & $0.36 \pm 0.02$ & $70 \pm 4$ & $0.59 \pm 0.04$ & $0.45 \pm 0.01$ \\
\hline $40^{\circ} \mathrm{C}, \mathrm{RM}^{\text {OXOID }}$ & $0.37 \pm 0.02$ & $73 \pm 4$ & $0.61 \pm 0.03$ & $0.42 \pm 0.00$ \\
\hline $30^{\circ} \mathrm{C}, \mathrm{RM}^{\text {OXOID }}+5 \mathrm{~T}$ & $0.45 \pm 0.00$ & $89 \pm 1$ & $1.75 \pm 0.01$ & $0.49 \pm 0.01$ \\
\hline $36^{\circ} \mathrm{C}, \mathrm{RM}^{\text {OXOID }}+5 \mathrm{~T}$ & $0.43 \pm 0.04$ & $83 \pm 8$ & $2.19 \pm 0.22$ & $0.55 \pm 0.01$ \\
\hline $40{ }^{\circ} \mathrm{C}, \mathrm{RM}^{\text {OXOID }}+5 \mathrm{~T}$ & $0.44 \pm 0.02$ & $85 \pm 4$ & $2.23 \pm 0.11$ & $0.53 \pm 0.01$ \\
\hline
\end{tabular}

It also increased cell growth, glucose consumption rate, and ethanol productivity of ZM4 at higher temperatures of 36 and $40^{\circ} \mathrm{C}$ than those at the normal temperature of $30^{\circ} \mathrm{C}$ in RM ${ }^{\text {OXOID }}$ supplemented with $5 \mathrm{~g} / \mathrm{L}$ tryptone, although ethanol yields were similar among these conditions (Table 1, Fig. 3). Compared with normal temperature $30^{\circ} \mathrm{C}$, the time that ZM4 utilized all glucose at 36 and $40{ }^{\circ} \mathrm{C}$ in $\mathrm{RM}^{\mathrm{OXOID}}$ with extra tryptone was reduced by about $3 \mathrm{~h}$, while one day was not sufficient for ZM4 to completely consume glucose at 30,36 , and $40^{\circ} \mathrm{C}$ in RM ${ }^{\mathrm{OXOID}}$ (Fig. 3). ZM4 took less time to completely utilize glucose with maximum ethanol production achieved in $\mathrm{RM}^{\mathrm{OXOID}}+5 \mathrm{~T}$ at 36 and $40^{\circ} \mathrm{C}(9 \mathrm{~h})$ than at $30{ }^{\circ} \mathrm{C}(12 \mathrm{~h})$ with a corresponding higher growth rate and ethanol productivity, which was increased from $1.75 \pm 0.01$ at $30{ }^{\circ} \mathrm{C}$ to $2.19 \pm 0.22$ and $2.23 \pm 0.11$ at 36 and $40{ }^{\circ} \mathrm{C}$, respectively (Table 1 , Fig. 3 ).

\section{Effect of exchanging yeast extract from OXOID with different brand ones in RM}

As briefly mentioned above that yeast extracts distributed by different companies are produced with different processes leading to difference in the amount of total nitrogen as well as trace elements such as growth factors and metal ions. Besides adding extra nitrogen source into the RM ${ }^{\text {OXOID }}$ as discussed above (Fig. 1, 2, 3), we also tested the effect of yeast extract from different companies including those from Becton Dickinson (YE ${ }^{\mathrm{BD}}$ ) and Sangon Biotech Co., Ltd (YE ${ }^{\mathrm{SG}}$, Shanghai, China). In addition, another industrial nitrogen source of corn steep liquid (CSL) from Macklin was also evaluated at the same time with above two yeast-based nitrogen sources. All media used in this research were list in Table 3 and Table 4. 
$\mathrm{YE}^{\mathrm{OXOID}}$ in RM ${ }^{\mathrm{OXOID}}$ was replaced with different nitrogen sources including peptone $(\mathrm{P})$, tryptone $(\mathrm{T}), \mathrm{CSL}$, $\mathrm{YE}^{\mathrm{BD}}$, and $\mathrm{YE}^{\mathrm{SG}}$. Cell growth, glucose utilization, and ethanol production of $\mathrm{ZM} 4$ cultured in these media were then examined. Our results showed ZM4 performed differently in these media (Fig. 4). The biomass of ZM4 in RM(T) was about two times higher than that in RM ${ }^{\text {OXOID }}$, while the biomass of ZM4 in RM(P) was the lowest (Fig. 4B). It seemed that tryptone was better than $\mathrm{YE}^{\mathrm{OXOID}}$ and peptone, which was consistent with above experiments of supplementation of nitrogen source into RM ${ }^{\text {OXOID }}$ (Fig. 1, 2).

Except that the specific growth rates which can be seen from the slopes of the lines in exponential phase of ZM4 in RM with $1 \%$ of peptone or CSL as the sole nitrogen source were lower, the specific growth rates of ZM4 in other RM were almost the same (Fig. 4A). Compared with YEOXOID as the sole nitrogen source, $Y E^{B D}, Y E^{S G}$ and $5 \% C S L$ all increased the final biomass of $Z M 4$ (Fig. 4B), reduced the time of glucose consumption (Fig. 4C), and made cell growth and ethanol production coupled. For example, the biomass of $\mathrm{ZM} 4$ in $\mathrm{RM}^{\mathrm{BD}}$ was three times more than that in $\mathrm{RM}^{\mathrm{OXO}}$, the time for complete glucose utilization in $\mathrm{RM}^{\mathrm{BD}}$ was about two-thirds shorter than that in $\mathrm{RM}^{\mathrm{OXOID}}$ (Fig. 4B, C). $\mathrm{YE}^{\mathrm{SG}}$ was almost as good as $\mathrm{YE}^{\mathrm{BD}}$ with lower cost, which can be used in large-scale fermentation for economic ethanol production, and appropriate nitrogen source can be chosen as needed based on above results (Fig. 1, 2, 3, 4).

\section{Effect of exchanging $\left(\mathrm{NH}_{4}\right)_{2} \mathrm{SO}_{4}$ in $\mathrm{MM}$ with different organic nitrogen sources}

Although the RM recipe is relatively simple containing only three ingredients as discussed above, the composition of organic nitrogen sources such as yeast extract is still complicated containing nitrogen, vitamins, metal ions etc. Minimum medium (MM) was therefore selected to further examine the effect of different organic nitrogen sources on ZM4 since the only nitrogen source in MM is the inorganic nitrogen source $\left(\mathrm{NH}_{4}\right)_{2} \mathrm{SO}_{4}$. The representative organic nitrogen sources used to replace $\left(\mathrm{NH}_{4}\right)_{2} \mathrm{SO}_{4}$ in $\mathrm{MM}$ included $\mathrm{YE}^{\mathrm{BD}}, \mathrm{YE} \mathrm{OXOID}^{\mathrm{O}}$, and 5\%CSL.

Our results demonstrated that the replacement of inorganic nitrogen source $\left(\mathrm{NH}_{4}\right)_{2} \mathrm{SO}_{4}$ with organic nitrogen source enhanced cell growth, glucose utilization, and ethanol productivity (Fig. 5). Interestingly, ZM4 had similar growth and glucose consumption rates in two MM media with $\mathrm{YE}^{\mathrm{BD}}$ or $\mathrm{YE}{ }^{\mathrm{OXOID}}$ as the sole nitrogen source (Fig. 5), which was different from those when $\mathrm{YE}^{\mathrm{BD}}$ or $\mathrm{YE}{ }^{\mathrm{OXO} O \mathrm{D}}$ was used as the sole nitrogen source in RM (Fig. 4). ZM4 grew better in RM with $\mathrm{YE}^{\mathrm{BD}}$ than that with $\mathrm{YE} \mathrm{EXOID}^{\mathrm{O}}$ as the nitrogen source (Fig. 4). Therefore, some ingredients must be existing in MM that RM lacks when YE ${ }^{\mathrm{OXOID}}$ was used as the nitrogen source, which leaves to the compositions of $\mathrm{NaCl}$ and metal ions of $\mathrm{Na}_{2} \mathrm{MoO}_{4}$ and $\mathrm{MgSO}_{4}$ that are different in the ingredients of these two media $($ Table 3, 4).

Since metal ions of magnesium and molybdenum are the cofactors of enzymes involving in various metabolic activities, we thus investigated the effect of metal ions of $\mathrm{MgSO}_{4}$ and $\mathrm{Na}_{2} \mathrm{MoO}_{4}$ by removing them from both $\mathrm{MM}^{\mathrm{BD}}$ and $\mathrm{MM}^{\mathrm{OXO} \mathrm{OD}}$ to test the growth and fermentation performance of ZM4. The lack 
of $\mathrm{Mg}^{2+}$ and $\mathrm{MoO}_{4}{ }^{2-}$ in $\mathrm{MM}^{\mathrm{BD}}$ had no effect on the growth of $\mathrm{ZM} 4$, but ZM4 had a delay period in $\mathrm{MM}^{\text {OXOID }}$ lacking $\mathrm{MoO}_{4}{ }^{2-}$, and the biomass decreased in $\mathrm{MM}^{\mathrm{OXOID}}$ lacking $\mathrm{Mg}^{2+}$ (Fig. 6). Apparently, this result indicated that $\mathrm{MoO}_{4}{ }^{2-}$ and $\mathrm{Mg}^{2+}$ in $\mathrm{YE}^{\mathrm{OXOID}}$ were different from those in $\mathrm{YE}^{\mathrm{BD}}$. $\mathrm{MoO}_{4}{ }^{2-}$ and $\mathrm{Mg}^{2+}$ played important role on cell growth of $\mathrm{Z}$. mobilis, and $\mathrm{Mg}^{2+}$ probably was the factor affecting the coupling of cell growth and ethanol production.

\section{Determination of concentrations of ions in different nitrogen sources and the impact of the $\mathrm{Mg}^{2+}$ on fermentation performance}

In order to verify this hypothesis, the concentrations of several major ion elements in different organic nitrogen sources were then measured by ICP-OES. The result showed that the concentrations of these ion elements ( $\mathrm{Fe}, \mathrm{K}, \mathrm{Mg}, \mathrm{P}, \mathrm{S})$ were different among different nitrogen sources with less of these ions containing in peptone and tryptone (Table 2), which probably could be one of the reasons that cell growth and fermentation performance of Z. mobilis in media using tryptone and peptone as the sole nitrogen source was not as good as in other media using yeast extract or yeast powder.

At the same concentration of nitrogen sources, the $\mathrm{Mg}^{2+}$ in the yeast extract from OXOID was $8.23 \mathrm{mg} / \mathrm{L}$ less than that from Becton Dickinson. $\mathrm{Mg}^{2+}$ is the component with major difference between these two nitrogen sources of yeast extract from OXOID and BD companies, and therefore could be the reason that cell growth and ethanol fermentation of $Z$. mobilis in RM ${ }^{\text {OXOID }}$ was not as good as in RM ${ }^{B D}$ (Table 2). Since $0.5 \mathrm{~g} / \mathrm{L} \mathrm{MgSO}_{4} \cdot 7 \mathrm{H}_{2} \mathrm{O}$ containing $49 \mathrm{mg} / \mathrm{L} \mathrm{Mg}^{2+}$ was provided in MM which was sufficient for cell growth (Table 2, 4), the growth difference of $Z$. mobilis in $\mathrm{MM}^{\mathrm{OXOID}}$ and $\mathrm{MM}^{\mathrm{BD}}$ was therefore not as obvious as that in RM ${ }^{\mathrm{OXOID}}$ and $\mathrm{RM}^{\mathrm{BD}}$ (Fig. 4, 5). The concentration of $\mathrm{Mg}^{2+}$ in peptone was the lowest, which could also be one of the reasons that ZM4 grew poorly in $\mathrm{RM}(\mathrm{P})$ compared with other nitrogen sources (Fig. 4). These results further confirmed the importance of sufficient $\mathrm{Mg}^{2+}$ concentration in the media for optimal cell growth and ethanol fermentation. 
Table 2

Concentrations of different ion elements in different nitrogen sources measured by ICP-OES.

\begin{tabular}{|lllllll|}
\hline lon(mg/L) & $1 \% \mathrm{CSL}$ & $1 \% \mathrm{YE}^{\mathrm{OXOID}}$ & $1 \% \mathrm{YE}^{\mathrm{BD}}$ & $1 \% \mathrm{YE}^{\mathrm{SG}}$ & $1 \%$ Peptone & $1 \%$ Tryptone \\
\hline $\mathrm{Fe}$ & 0.48 & 0.51 & 0.42 & 0.28 & 0.13 & 0.13 \\
$\mathrm{~K}$ & 280.71 & 492.74 & 456.13 & 311.83 & 5.52 & 1.07 \\
$\mathrm{Mg}$ & 9.72 & 2.83 & 11.07 & 18.45 & 0.06 & 2.72 \\
$\mathrm{Mo}$ & 0.03 & 0.0009 & 0.004 & 0.0008 & 0.0089 & 0.0072 \\
$\mathrm{Na}$ & 20.61 & 19.16 & 48.83 & 131.30 & 27.80 & 49.56 \\
$\mathrm{P}$ & 198.13 & 159.72 & 129.10 & 278.30 & 2.67 & 16.65 \\
\hline $\mathrm{S}$ & 56.88 & 58.69 & 85.92 & 65.59 & 5.21 & 17.04 \\
\hline
\end{tabular}

To verify the impact of $\mathrm{Mg}^{2+}$ on cell growth, different concentrations of $\mathrm{Mg}^{2+}$ were then added into the $\mathrm{RM}^{\mathrm{OXOID}}$ and $\mathrm{MM}^{\mathrm{OXOID}}$ without $\mathrm{MgSO}_{4}\left(\mathrm{MM}^{\mathrm{OXOID}} \triangle \mathrm{MgSO}_{4}\right)$, and the growth of ZM4 in these media was measured by the Bioscreen $\mathrm{C}$ (Fig. 7). Our results indicated that in both $\mathrm{RM}^{\mathrm{OXOID}}$ and $\mathrm{MM}^{\mathrm{OXOID}} \triangle \mathrm{MgSO}_{4}$, even a small amount of $\mathrm{Mg}^{2+}$ at $4 \mathrm{mg} / \mathrm{L}$ could obviously boost cell growth.

The cell growth, glucose utilization, and ethanol production were further investigated using the shake flask experiment with $\mathrm{OD}_{600}$ values, glucose and ethanol concentrations measured (Fig. 8). Consistent with the result of Bioscreen $\mathrm{C}$ (Fig. 7), the supplementation of at least $8 \mathrm{mg} / \mathrm{L}$ of $\mathrm{Mg}^{2+}$ in RM ${ }^{\text {OXOID }}$ or $\mathrm{MM}^{\mathrm{OXOID}} \triangle \mathrm{MgSO}_{4}$ allowed $\mathrm{ZM} 4$ to grow as well as in $\mathrm{RM}^{\mathrm{BD}}$ or $\mathrm{MM}^{\mathrm{BD}} \triangle \mathrm{MgSO}_{4}$. At the same time, cell growth, glucose consumption, and ethanol production of ZM4 in RM ${ }^{\text {OXOID }}$ with $8 \mathrm{mg} / \mathrm{L} \mathrm{Mg}^{2+}$ added were coupled as in $\mathrm{RM}^{\mathrm{BD}}$ (Fig. 8), which suggested that $\mathrm{Mg}^{2+}$ is crucial for cell growth and fermentation performance of Z. mobilis, and a minimal concentration of at least $8 \mathrm{mg} / \mathrm{L}$ is needed for optimal cell growth and ethanol fermentation.

\section{Effects of $\mathrm{Mg}^{2+}$ on gene expression of $\mathrm{Z}$. mobilis}

After confirmation of the impact of $\mathrm{Mg}^{2+}$ on cell growth and ethanol fermentation of Z. mobilis (Fig. 8), next-generation sequencing (NGS)-based RNA-Seq transcriptomics was further applied to identify genes responsive for the uncoupling of cell growth and ethanol fermentation due to the difference of $\mathrm{Mg}^{2+}$ concentration in the medium.

Despite that glucose consumption, cell growth, and ethanol production exhibited apparent difference (Fig. 8), RNA-Seq result showed that only a few genes differentially expressed. There were 7 and 4 genes down-regulated when Z. mobilis was cultured in $\mathrm{RM}^{\mathrm{OXOID}}$ and $\mathrm{RM}^{\mathrm{BD}}\left(\mathrm{RM}^{\mathrm{OXOID}} / \mathrm{RM}^{\mathrm{BD}}\right.$, Fig. 9A, Table S1) as well as cultured in $\mathrm{RM}$ and $\mathrm{RM}^{\mathrm{OXOID}}+8 \mathrm{Mg}\left(\mathrm{RM}^{\mathrm{OXOID}} / \mathrm{RM}^{\mathrm{OXOID}}+8 \mathrm{Mg}\right.$, Fig. 9B, Table S2), respectively. 
Although genes up-regulated in RM ${ }^{\text {OXOID }}$ were more than those down-regulated (Fig. 9, Table S1, S2), there were still only 11 and 10 up-regulated when Z. mobilis was cultured in RM ${ }^{\text {OXOID }}$ and $\mathrm{RM}^{\mathrm{BD}}$ (RM ${ }^{\mathrm{OXOID}} / \mathrm{RM}^{\mathrm{BD}}$, Fig. 9A, Table S1) as well as cultured in $\mathrm{RM}^{\mathrm{OXOID}}$ and $\mathrm{RM}^{\mathrm{OXOID}}+8 \mathrm{Mg}$ $\left(\mathrm{RM}^{\mathrm{OXOID}} / \mathrm{RM}^{\mathrm{OXOID}}+8 \mathrm{Mg}\right.$, Fig. 9B, Table S2), respectively. Two and eight of these down-regulated and upregulated ones are common between these two comparisons (Fig. 9, Table S1, S2).

Genes related to stress responses were up-regulated while genes related to protein secretion were downregulated in $\mathrm{RM}^{\mathrm{OXOID}}$ medium compared with in $\mathrm{RM}^{\mathrm{OXOID}}+8 \mathrm{Mg}$ or $\mathrm{RM}^{\mathrm{BD}}$ medium (Fig. 9, Table S1, S2). For example, genes encoding catalase (ZM00918), general stress protein CsbD (ZMO0740), NADH dehydrogenase (ZM01113), and succinate-semialdehyde dehydrogenase SSADH (ZMO1754) were upregulated when $\mathrm{RM}^{\mathrm{OXOID}}$ was used compared with those in $\mathrm{RM}^{\mathrm{OXOID}}+8 \mathrm{Mg}$ or $\mathrm{RM}^{\mathrm{BD}}$ (Fig. 9, Table S1, S2). These results indicated that $\mathrm{Mg}^{2+}$, a key element of cofactor, is essential for vigorous cell growth, and the lack of $\mathrm{Mg}^{2+}$ will trigger energy-consuming stress responses while slowing down energy-consuming metabolism with genes encoding levansucrase (ZM00374) and protein secretion-related (ZMO0934) down-regulated (Fig. 9, Table S1, S2).

Considering the facts that the supplementation of $8 \mathrm{mg} / \mathrm{L} \mathrm{Mg}^{2+}$ into RM ${ }^{\mathrm{OXOID}}(\mathrm{RM}+8 \mathrm{Mg})$ could restore the coupling of cell growth and ethanol fermentation of Z. mobilis (Fig. 8), and there were only one gene up-regulated (ZMO2034) and one down-regulated (ZMO1522) when Z. mobilis grew in RM ${ }^{\mathrm{BD}}$ compared with RM + $8 \mathrm{Mg}$ (Fig. 9C), the transcriptomics study also further confirmed our hypothesis that the difference of $\mathrm{Mg}^{2+}$ concentrations in different nitrogen sources is one of the determinants affecting the coupling of cell growth and ethanol fermentation in Z. mobilis.

\section{Conclusion}

The uncoupling of cell growth and fermentation will increase the cost of microbial biochemical production. The effects of nitrogen sources on cell growth and ethanol fermentation performance of $Z$. mobilis ZM4 were investigated to understand the uncoupling of cell growth and ethanol fermentation of ZM4 in this study. Through the supplementation and replacement of inorganic or organic nitrogen sources in both $\mathrm{RM}$ and $\mathrm{MM}$, we found that $\mathrm{YE}^{\mathrm{BD}}, \mathrm{YE}^{\mathrm{SG}}$, or $5 \% \mathrm{CSL}$ were better than $\mathrm{YE}^{\mathrm{OXOID}}$. We also quantified the ion elements in different nitrogen sources using ICP-OES, and demonstrated that the difference of metal ions of $\mathrm{MgSO}_{4}$ and $\mathrm{Na}_{2} \mathrm{MoO}_{4}$ in yeast extract could be one of the major factors affecting cell growth and ethanol fermentation. We further verified the impact of $\mathrm{Mg}^{2+}$ on cell growth of ZM4 by supplementing various concentrations of $\mathrm{Mg}^{2+}$ into the medium, and identified genes involved in stress response and energy conservation responsive for the uncoupling of cell growth and ethanol fermentation when the medium was lack of $\mathrm{Mg}^{2+}$ using RNA-Seq transcriptomics approach. These findings can be used as a reference for the selection and/or modification of nitrogen sources for economic ethanol production using Z. mobilis ZM4. The concentrations of ion elements in nitrogen sources affecting cell growth and fermentation performance can also be used as a parameter for 
optimizing and monitoring the components of nitrogen sources for efficient cell growth and fermentation using other microorganisms.

\section{Materials And Methods}

\section{Bacterial strain, media and growth conditions}

Zymomonas mobilis ZM4 (ATCC 31821) was revived from frozen glycerol stocks in $10 \mathrm{~mL}$ RMG5 (5\% glucose, $10 \mathrm{~g} / \mathrm{L}$ yeast extract, $2 \mathrm{~g} / \mathrm{L} \mathrm{KH}_{2} \mathrm{PO}_{4}$ ) at $30{ }^{\circ} \mathrm{C}$ for about $6 \sim 8 \mathrm{~h}$ prior to inoculating overnight seed cultures at $30{ }^{\circ} \mathrm{C}$ at $100 \mathrm{rpm}$ in RMG5 (5\% glucose) using shake flasks filled to $80 \%$ capacity. Glucose, $\mathrm{KH}_{2} \mathrm{PO}_{4}, \mathrm{~K}_{2} \mathrm{HPO}_{4}, \mathrm{NaCl}, \mathrm{MgSO}_{4} \cdot 7 \mathrm{H}_{2} \mathrm{O}, \mathrm{Na}_{2} \mathrm{MoO}_{4} \cdot 2 \mathrm{H}_{2} \mathrm{O}$ and $\mathrm{NH}_{4} \mathrm{Cl}$ were purchased from Sinopharm Chemical Reagent Co., Ltd (Shanghai, China). Yeast extract (YE) was purchased from OXOID, Becton Dickinson, and Sangon Biotech (Shanghai) Co., Ltd (Shanghai, China). Tryptone was purchased from OXOID. Peptone was purchased from Becton Dickinson. Corn steep liquid (CSL) was purchased from Shanghai Macklin Biochemical Co., Ltd (Shanghai, China).

The recipes of different rich medium (RM) and minimum medium (MM) with different nitrogen sources used in this work were listed in Tables 3 and 4, respectively.

Table 3

Recipes of different rich medium (RM) with different nitrogen sources used in this work. YE: Yeast extract; CSL: corn steep liquid. +: with the component in the medium. The media supplemented with CSL were filter-sterilized, others were autoclaved $\left(108^{\circ} \mathrm{C}, 30 \mathrm{~min}\right)$.

\begin{tabular}{|c|c|c|c|}
\hline Media & Glucose $(50 \mathrm{~g} / \mathrm{L})$ & $\mathrm{KH}_{2} \mathrm{PO}_{4}(2 \mathrm{~g} / \mathrm{L})$ & Nitrogen Source \\
\hline $\mathrm{RM}(\mathrm{P})$ & + & + & Peptone \\
\hline $\mathrm{RM}(\mathrm{T})$ & + & + & Tryptone \\
\hline $\mathrm{RM}(\mathrm{CSL})$ & + & + & CSL $(10 \mathrm{~g} / \mathrm{L})$ \\
\hline $\mathrm{RM}(5 \% \mathrm{CSL})$ & + & + & $\operatorname{CSL}(50 \mathrm{~g} / \mathrm{L})$ \\
\hline $\mathrm{RM}^{\mathrm{BD}}$ & + & + & $Y E^{B D}$ \\
\hline $\mathrm{RM}^{\mathrm{SG}}$ & + & + & $\mathrm{YE}^{\mathrm{SG}}$ \\
\hline $\mathrm{RM}^{\mathrm{OXOID}}$ & + & + & YE OXOID \\
\hline$R M+P$ & + & + & $\mathrm{YE} \mathrm{OXOID}^{-}$peptone \\
\hline$R M+T$ & + & + & YE ${ }^{\mathrm{OXOID}}+$ tryptone \\
\hline
\end{tabular}


Table 4

Recipes of different minimum medium (MM) with different nitrogen sources and metal ions of $\mathrm{Mg}^{2+}$ and $\mathrm{MoO}_{4}{ }^{2-}$ used in this work. YE: Yeast extract; CSL: corn steep liquid. All media contained ingredients of glucose $(20 \mathrm{~g} / \mathrm{L}), \mathrm{K}_{2} \mathrm{HPO}_{4}(1 \mathrm{~g} / \mathrm{L}), \mathrm{KHP}_{2} \mathrm{O}_{4}(1 \mathrm{~g} / \mathrm{L})$, and $\mathrm{NaCl}(0.5 \mathrm{~g} / \mathrm{L})$. + : with the component in the medium; $-:$ without the component in the medium. The media supplemented with $\mathrm{CSL}$ were filter-sterilized, others were autoclaved $\left(108^{\circ} \mathrm{C}, 30 \mathrm{~min}\right)$. After the autoclavation, the filtersterilized $\mathrm{Na}_{2} \mathrm{MoO}_{4}$ and $\mathrm{MgSO}_{4}$ were then added into the media.

\begin{tabular}{|llll|}
\hline Media & Nitrogen sources & $\mathrm{MgSO}_{4} \cdot 7 \mathrm{H}_{2} \mathrm{O}(0.5 \mathrm{~g} / \mathrm{L})$ & $\mathrm{Na}_{2} \mathrm{MoO}_{4} \cdot 2 \mathrm{H}_{2} \mathrm{O}(0.025 \mathrm{~g} / \mathrm{L})$ \\
\hline $\mathrm{MM}$ & $\left(\mathrm{NH}_{4}\right)_{2} \mathrm{SO}_{4}(1 \mathrm{~g} / \mathrm{L})$ & + & + \\
$\mathrm{MM}(5 \% \mathrm{CSL})$ & $\mathrm{CSL}(50 \mathrm{~g} / \mathrm{L})$ & + & + \\
$\mathrm{MM}$ OXOID & $\mathrm{YE}^{\mathrm{OXOID}}(10 \mathrm{~g} / \mathrm{L})$ & + & + \\
$\mathrm{MM}^{\mathrm{BD}}$ & $\mathrm{YE}^{\mathrm{BD}}(10 \mathrm{~g} / \mathrm{L})$ & + & - \\
$\mathrm{MM}^{\mathrm{OXOID}} \triangle \mathrm{Na}_{2} \mathrm{MoO}_{4}$ & $\mathrm{YE}^{\mathrm{OXOID}}(10 \mathrm{~g} / \mathrm{L})$ & + & - \\
$\mathrm{MM}^{\mathrm{BD}} \triangle \mathrm{Na}_{2} \mathrm{MoO}_{4}$ & $\mathrm{YE}^{\mathrm{BD}}(10 \mathrm{~g} / \mathrm{L})$ & + & + \\
$\mathrm{MM}^{\mathrm{OXOID}} \triangle \mathrm{MgSO}_{4}$ & $\mathrm{YE}^{\mathrm{OXOID}}(10 \mathrm{~g} / \mathrm{L})$ & - & + \\
$\mathrm{MM}^{\mathrm{BD}} \triangle \mathrm{MgSO}_{4}$ & $\mathrm{YE}^{\mathrm{BD}}(10 \mathrm{~g} / \mathrm{L})$ & - & + \\
\hline
\end{tabular}

\section{Growth test by Bioscreen C}

The seed culture of Z. mobilis was centrifuged to remove RM medium. Cells were resuspended with test medium. Bioscreen $C$ assays were carried out as described previously [16, 27-31] except that cells were inoculated into Bioscreen $C$ wells containing a total volume of $200 \mu \mathrm{L}$ test medium at an initial $\mathrm{OD}_{600}$ value of 0.05 and incubated without shaking at $30^{\circ} \mathrm{C}$. Triplicate were used for each condition, and turbidity measurements $\left(\mathrm{OD}_{600}\right)$ were taken every 15 min till cells grew into stationary phase.

\section{Flask fermentation and analytical analysis}

The seed culture of Z. mobilis was used to inoculate shake flask containing $80 \%$ of test medium at an initial $\mathrm{OD}_{600}$ of 0.1 , and cultured at $30{ }^{\circ} \mathrm{C}, 100 \mathrm{rpm}$. At least two replicates were used for each condition.

The $\mathrm{OD}_{600}$ values of the bacterial culture was measured by UV-visible spectrophotometer UV- 1800 (AoYi Instrument Co., Ltd, Shanghai, China) every $3 \mathrm{~h}$. At the same time, 1-mL culture was centrifuged at $12,000 \mathrm{rpm}$ for $1 \mathrm{~min}$ to obtain the supernatant for measuring the glucose and ethanol concentrations in the culture. Biosensor analyzer M-100 (Sieman Technology Co., Ltd., Shenzhen, China) was used for quick assessment of the concentrations of glucose and ethanol. The supernatant was also filtered 
through a $0.45-\mu \mathrm{m}$ filter before applying on a Shimadzu LC-2030 high pressure liquid chromatography (HPLC) with refractive index detector (RID). Bio-Rad Aminex HPX-87H ( $300 \times 7.8 \mathrm{~mm})$ column was used to separate the fermentation products, and $0.005 \mathrm{M} \mathrm{H}_{2} \mathrm{SO}_{4}$ was used as the mobile phase at a flow rate of $0.5 \mathrm{~mL} / \mathrm{min}$. Temperatures of detector and column were 40 and $60^{\circ} \mathrm{C}$, respectively.

One percent ( $w / v)$ of different organic nitrogen sources were prepared in $\mathrm{ddH}_{2} \mathrm{O}$ and then filter-sterilized. The concentrations of different ions in these samples were then measured by Inductively Coupled Plasma Optical Emission Spectroscopy (ICP-OES, Wuhan SouSepad Testing Technology Co., Ltd., Wuhan, China).

\section{Ethanol production calculations}

Cell growth was monitored the optical density with spectrophotometrically at $600 \mathrm{~nm}$. The time points when cells reached stationary phase as well as glucose was completely consumed with the maximum ethanol produced were recorded. The concentrations of glucose and ethanol determined by HPLC or Biosensor analyzer $\mathrm{M}-100$ were then used for the calculation of the ethanol yield $\left(\mathrm{Y}_{\mathrm{p} / \mathrm{s}}\right)$, theoretical ethanol yield $\left(\% Y_{p / s}\right)$, ethanol productivity $\left(Q_{P}\right)$, and specific growth rate $(\mu)$ using the formula below:

$\mathrm{Y}_{\mathrm{p} / \mathrm{s}}=$ maximum ethanol $(\mathrm{g}) /$ consumed glucose $(\mathrm{g})$;

$\% \mathrm{Y}_{\mathrm{p} / \mathrm{s}}=($ ethanol $(\mathrm{g}) /($ consumed sugar $(\mathrm{g}) * 0.511)) * 100 ;$

$Q_{P}=$ maximum ethanol titer $(\mathrm{g} / \mathrm{L}) /$ time to reach the maximum ethanol.

$\mu=\ln \left(\left(\mathrm{OD}_{600}\right.\right.$ at $\left.\mathrm{t}_{2}\right) /\left(\mathrm{OD}_{600}\right.$ at $\left.\left.\mathrm{t}_{1}\right)\right) /\left(\mathrm{t}_{2}-\mathrm{t}_{1}\right), \mathrm{t}_{1}$ and $\mathrm{t}_{2}$ are the time points in log phase.

\section{Transcriptomic analysis}

Transcriptomics study was followed previous work [16, 29, 31-35]. Briefly, cell culture samples were collected during exponential phase with the $\mathrm{OD}_{600}$ values around $0.6 \sim 0.8$. RNA-Seq were performed using the paired-end sequencing technology according to standard Illumina protocols (Genewiz Inc, Suzhou, China). The quality of RNA-Seq fastq data was evaluated using FastQC software (Babraham Bioinformatics, UK). Data passing the quality control were imported into CLC Genomics Workbench (Ver. 11.0) for RNA-Seq analysis to get the RPKM value (reads mapping to the genome per kilobase of transcript per million reads sequenced) of each gene with the reference genome. Genome sequence of $Z$. mobilis was used as the reference for RPKM calculation [33, 36]. The RPKM value of each gene was then imported into JMP Genomics (Ver. 9.0), and data normalization and statistical analysis were conducted to identify differentially expressed genes when three different media were used. Duplicate samples were used for each condition.

\section{Abbreviations}


CSL:corn steep liquid; ED:Entner-Doudoroff; EMP:Embden-Meyerhof-Parnas; GRAS:generally regarded as safe status; MM:minimum medium; ICP-OES:Inductively Coupled Plasma Optical Emission Spectroscopy; $\mathrm{P}$ :peptone; $\mathrm{RM}$ :rich medium; $\mathrm{RM}^{\mathrm{BD}}$ :yeast extract in rich medium was from company Becton Dickinson (BD); $\mathrm{RM}^{\mathrm{OXOID}}$ :yeast extract in rich medium was from company OXOID; RPKM:reads mapping to the genome per kilobase of transcript per million reads sequenced; T:tryptone; TRY:titer, rate, and yield; YE:yeast extract.

\section{Declarations}

\section{Ethics approval and consent to participate}

The authors declare that this study does not involve human subjects, human material and human data.

\section{Consent for publication}

All authors read and approved the final manuscript.

\section{Availability of data and material}

The RNA-Seq raw data was deposited at Sequence Read Archive (SRA) database with the BioProject accession number PRJNA601020[1].

\section{Competing Interests}

The authors declare that they have no competing financial interests.

\section{Funding and acknowledgments}

This work was supported by the National Key Research and Development Program of China (2018YFA0900300), National Science Foundation of China (21978071 and U1932141), and the Technical Innovation Special Fund of Hubei Province (2019AHB055 and 2018ACA149). We also acknowledge the support from State Key Laboratory of Biocatalysis and Enzyme Engineering.

\section{Author's contributions}

SY conceived and designed the experiments with inputs from RL, MJ, SC, and JD. RL performed the experiments. RL and SY wrote the manuscript. MJ, SC and JD conducted the extensive manuscript review. All authors contributed to data analyses, read, revised and approved the final manuscript.

[1] https://dataview.ncbi.nlm.nih.gov/object/PRJNA601020?reviewer=n91gngs0m53png9gelrqnqh3af

\section{References}


1. Panesar PS, Marwaha SS, Kennedy JF: Zymomonas mobilis: an alternative ethanol producer. $J$ Chem Technol Biotechnol 2006, 81:623-635.

2. Rogers PL, Goodman AE, Heyes RH: Zymomonas ethanol fermentations. Microbio/ Sci 1984, 1:133136.

3. Rogers PL, Jeon YJ, Lee KJ, Lawford HG: Zymomonas mobilis for fuel ethanol and higher value products. Adv Biochem Eng Biotechnol 2007, 108:263-288.

4. He MX, Wu B, Qin H, Ruan ZY, Tan FR, Wang JL, Shui ZX, Dai LC, Zhu QL, Pan K, et al: Zymomonas mobilis. a novel platform for future biorefineries. Biotechnol Biofuels 2014, 7:101.

5. Wang X, He Q, Yang Y, Wang J, Haning K, Hu Y, Wu B, He M, Zhang Y, Bao J, et al: Advances and prospects in metabolic engineering of Zymomonas mobilis. Metab Eng 2018, 50:57-73.

6. Yang S, Fei Q, Zhang Y, Contreras LM, Utturkar SM, Brown SD, Himmel ME, Zhang M: Zymomonas mobilis as a model system for production of biofuels and biochemicals. Microb Biotechnol 2016, 9:699-717.

7. Conway T: The Entner-Doudoroff pathway: history, physiology and molecular biology. FEMS Microbiol Rev 1992, 9:1-27.

8. Dien BS, Cotta MA, Jeffries TW: Bacteria engineered for fuel ethanol production: current status. Appl Microbiol Biotechnol 2003, 63:258-266.

9. Kingston RL, Scopes RK, Baker EN: The structure of glucose-fructose oxidoreductase from Zymomonas mobilis. an osmoprotective periplasmic enzyme containing non-dissociable NADP. Structure 1996, 4:1413-1428.

10. Lawford HG, Rousseau JD: Corn steep liquor as a cost-effective nutrition adjunct in highperformance Zymomonas ethanol fermentations. App/ Biochem Biotechnol 1997, 63-65:287-304.

11. Ju NH, Damiano D, Shin CS, Kim NK, Wang SS: Continuous ethanol fermentation of Zymomonas mobilis using soy flour as a protective agent. Biotechnol Lett 1983, 5:837-842.

12. Kremer TA, LaSarre B, Posto AL, McKinlay JB: N2 gas is an effective fertilizer for bioethanol production by Zymomonas mobilis. Proc Natl Acad Sci USA 2015, 112:2222-2226.

13. Duan G, Wu B, Qin H, Wang W, Tan Q, Dai Y, Qin Y, Tan F, Hu G, He M: Replacing water and nutrients for ethanol production by ARTP derived biogas slurry tolerant Zymomonas mobilis strain. Biotechnol Biofuels 2019, 12:124.

14. Wu B, Qin H, Yang Y, Duan G, Yang S, Xin F, Zhao C, Shao H, Wang Y, Zhu Q, et al: Engineered Zymomonas mobilis tolerant to acetic acid and low pH via multiplex atmospheric and room temperature plasma mutagenesis. Biotechnol Biofuels 2019, 12:10.

15. Xia J, Liu CG, Zhao XQ, Xiao Y, Xia XX, Bai FW: Contribution of cellulose synthesis, formation of fibrils and their entanglement to the self-flocculation of Zymomonas mobilis. Biotechnol Bioeng 2018, 115:2714-2725.

16. Yang S, Franden MA, Brown SD, Chou YC, Pienkos PT, Zhang M: Insights into acetate toxicity in Zymomonas mobilis 8b using different substrates. Biotechnol Biofuels 2014, 7:140. 
17. He MX, Wu B, Shui ZX, Hu QC, Wang WG, Tan FR, Tang XY, Zhu QL, Pan K, Li Q, Su XH: Transcriptome profiling of Zymomonas mobilis under ethanol stress. Biotechnol Biofuels 2012, 5:75.

18. He MX, Wu B, Shui ZX, Hu QC, Wang WG, Tan FR, Tang XY, Zhu QL, Pan K, Li Q, Su XH: Transcriptome profiling of Zymomonas mobilis under furfural stress. App/ Microbiol Biotechnol 2012, 95:189-199.

19. Jones CW, Doelle HW: Kinetic control of ethanol production by Zymomonas mobilis. Applied Microbiology and Biotechnology 1991, 35:4-9.

20. Cot M, Loret MO, Francois J, Benbadis L: Physiological behaviour of Saccharomyces cerevisiae in aerated fed-batch fermentation for high level production of bioethanol. FEMS Yeast Res 2007, 7:2232.

21. Pagliardini J, Hubmann G, Alfenore S, Nevoigt E, Bideaux C, Guillouet SE: The metabolic costs of improving ethanol yield by reducing glycerol formation capacity under anaerobic conditions in Saccharomyces cerevisiae. Microb Cell Fact 2013, 12:29.

22. Pagliardini J, Hubmann G, Alfenore S, Nevoigt E, Bideaux C, Guillouet SE: The metabolic costs of improving ethanol yield by reducing glycerol formation capacity under anaerobic conditions in Saccharomyces cerevisiae. 2013, 12:29-29.

23. Yang Y, Hu M, Tang Y, Geng B, Qiu M, He Q, Chen S, Wang X, Yang S: Progress and perspective on lignocellulosic hydrolysate inhibitor tolerance improvement in Zymomonas mobilis. Bioresour Bioprocess 2018, 5:6.

24. Kemsawasd V, Viana T, Ardo Y, Arneborg N: Influence of nitrogen sources on growth and fermentation performance of different wine yeast species during alcoholic fermentation. App/ Microbiol Biotechnol 2015, 99:10191-10207.

25. Klotz S, Kuenz A, Prüße U: Nutritional requirements and the impact of yeast extract on the d-lactic acid production by Sporolactobacillus inulinus. Green Chem 2017, 19:4633-4641.

26. Martinez-Moreno R, Morales P, Gonzalez R, Mas A, Beltran G: Biomass production and alcoholic fermentation performance of Saccharomyces cerevisiae as a function of nitrogen source. FEMS Yeast Res 2012, 12:477-485.

27. Franden MA, Pienkos PT, Zhang M: Development of a high-throughput method to evaluate the impact of inhibitory compounds from lignocellulosic hydrolysates on the growth of Zymomonas mobilis. J Biotechnol 2009, 144:259-267.

28. Yang S, Franden MA, Yang Q, Chou YC, Zhang M, Pienkos PT: Identification of inhibitors in lignocellulosic slurries and determination of their effect on hydrocarbon-producing microorganisms. Front Bioeng Biotechnol 2018, 6:23.

29. Yang S, Land ML, Klingeman DM, Pelletier DA, Lu TY, Martin SL, Guo HB, Smith JC, Brown SD: Paradigm for industrial strain improvement identifies sodium acetate tolerance loci in Zymomonas mobilis and Saccharomyces cerevisiae. Proc Natl Acad Sci U S A 2010, 107:10395-10400.

30. Yang S, Mohagheghi A, Franden MA, Chou YC, Chen X, Dowe N, Himmel ME, Zhang M: Metabolic engineering of Zymomonas mobilis for 2,3-butanediol production from lignocellulosic biomass sugars. Biotechnol Biofuels 2016, 9:189. 
31. Yang S, Pan C, Hurst GB, Dice L, Davison BH, Brown SD: Elucidation of Zymomonas mobilis physiology and stress responses by quantitative proteomics and transcriptomics. Front Microbiol 2014, 5:246.

32. He Q, Yang Y, Yang S, Donohoe BS, Van Wychen S, Zhang M, Himmel ME, Knoshaug EP: Oleaginicity of the yeast strain Saccharomyces cerevisiae D5A. Biotechnol Biofuels 2018, 11:258.

33. Yang S, Vera JM, Grass J, Savvakis G, Moskvin OV, Yang Y, Mcllwain SJ, Lyu Y, Zinonos I, Hebert AS, et al: Complete genome sequence and the expression pattern of plasmids of the model ethanologen Zymomonas mobilis ZM4 and its xylose-utilizing derivatives 8b and 2032. Biotechnol Biofuels 2018, 11:125.

34. Yang S, Tschaplinski TJ, Engle NL, Carroll SL, Martin SL, Davison BH, Palumbo AV, Rodriguez M, Jr., Brown SD: Transcriptomic and metabolomic profiling of Zymomonas mobilis during aerobic and anaerobic fermentations. BMC Genomics 2009, 10:34.

35. Yang S, Pan C, Tschaplinski TJ, Hurst GB, Engle NL, Zhou W, Dam P, Xu Y, Rodriguez M, Jr., Dice L, et al: Systems biology analysis of Zymomonas mobilis ZM4 ethanol stress responses. PLoS One 2013, 8:e68886.

36. Yang S, Pappas KM, Hauser LJ, Land ML, Chen GL, Hurst GB, Pan C, Kouvelis VN, Typas MA, Pelletier DA, et al: Improved genome annotation for Zymomonas mobilis. Nat Biotechnol 2009, 27:893-894.

\section{Figures}

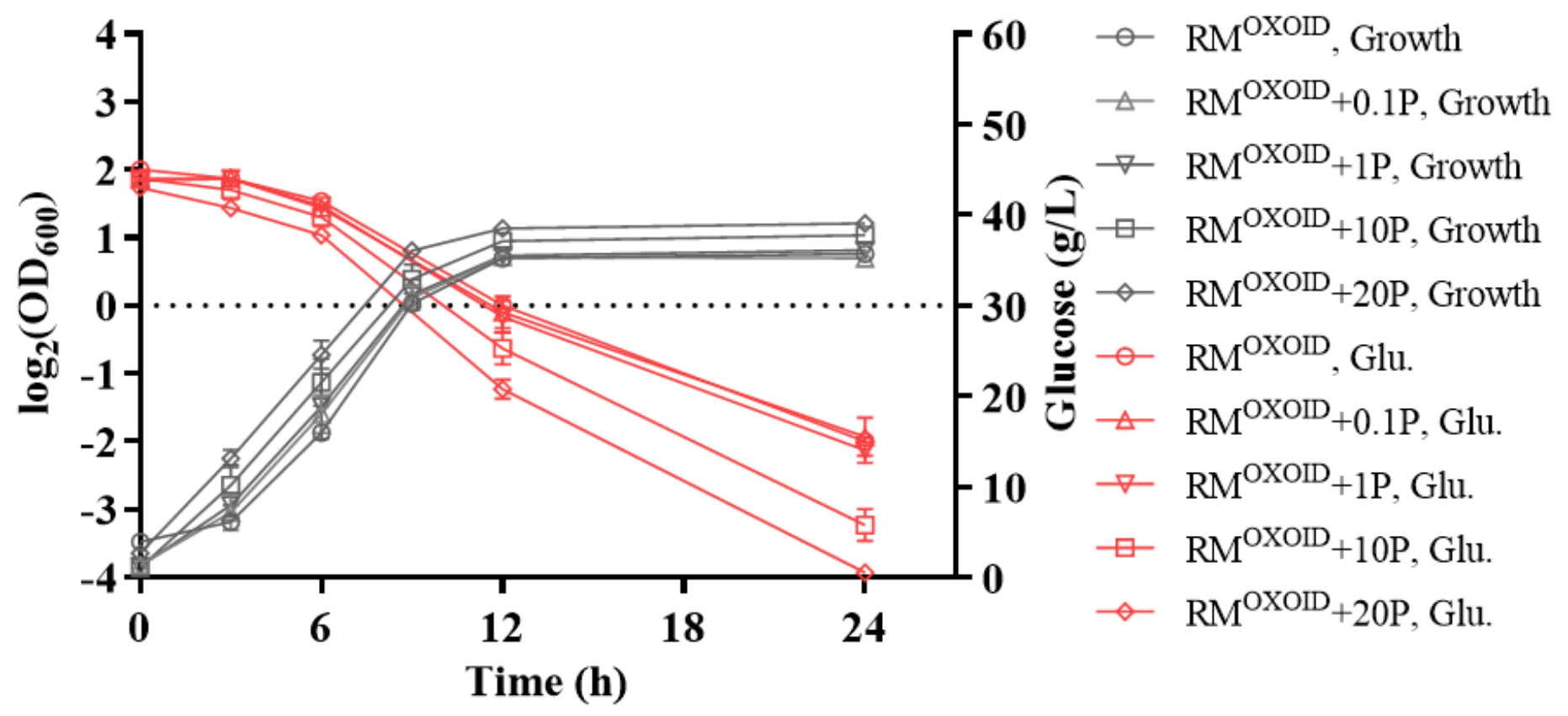

Figure 1 
Cell growth and glucose (Glu) consumption of ZM4 in rich medium (RM) using yeast extract from OXOID company (RMOXOID) with extra peptone $(P)$ supplemented at concentrations of $0.1,1,10$, and $20 \mathrm{~g} / \mathrm{L}$. At least two independent experiments were carried out with similar results. Values are the mean of one representative experiment with two or more technical replicates. Error bars represent standard deviations.
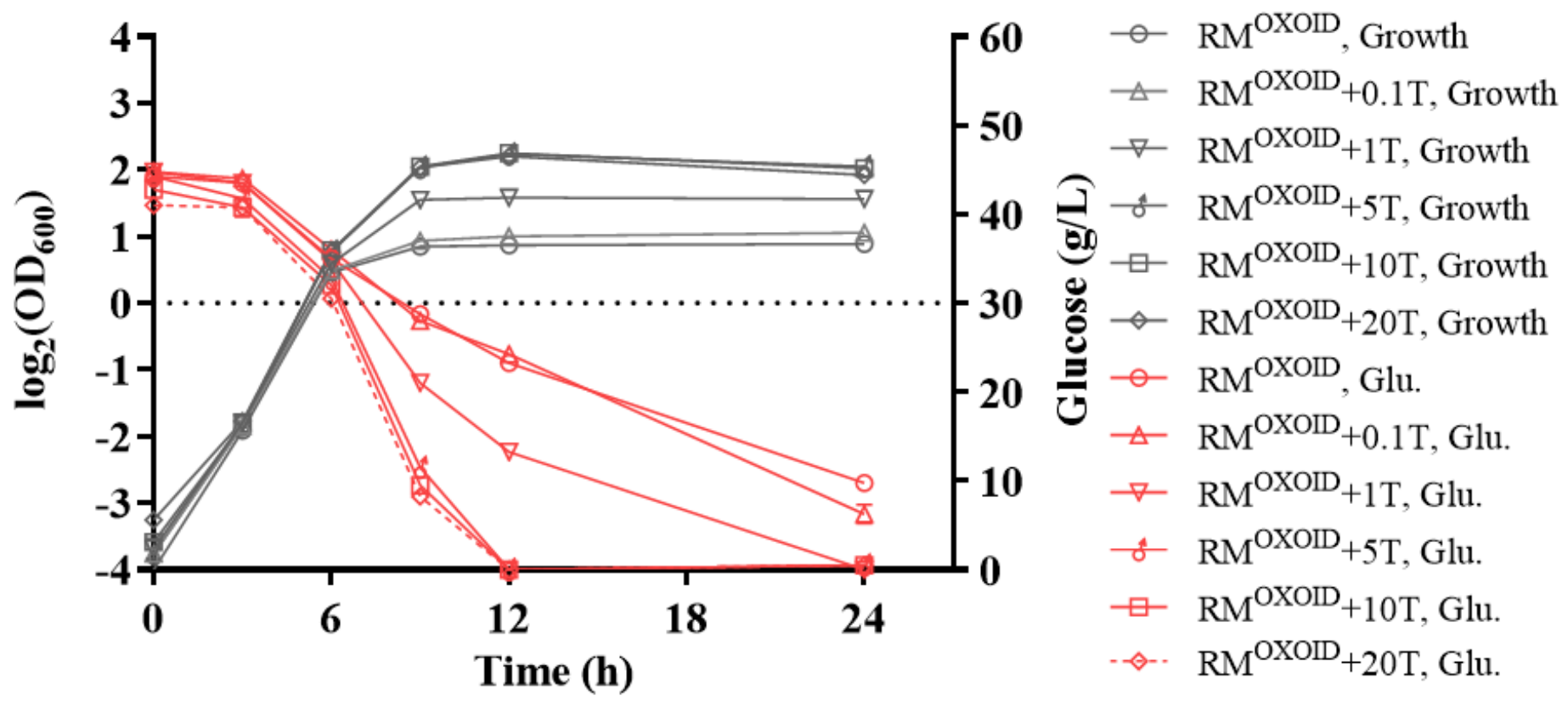

Figure 2

Cell growth and glucose (Glu) consumption of ZM4 in rich medium (RM) using yeast extract from OXOID company (RMOXOID) with extra tryptone (T) supplemented at concentrations of $0.1,1,5,10$, and $20 \mathrm{~g} / \mathrm{L}$. At least two independent experiments were carried out with similar results. Values are the mean of one representative experiment with two or more technical replicates. Error bars represent standard deviations. 

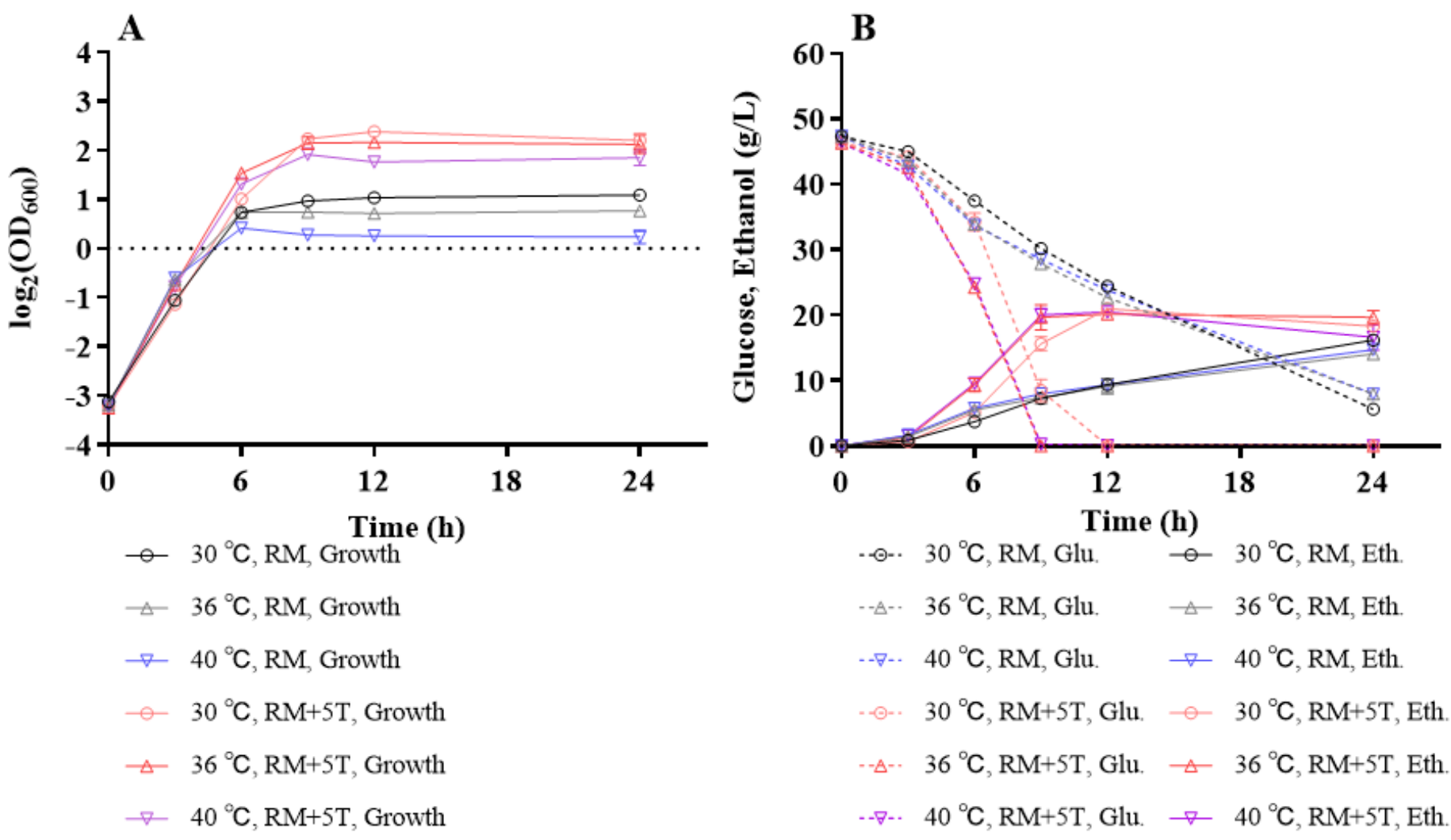

Figure 3

Cell growth (A), glucose (Glu) consumption and ethanol (Eth) production (B) of ZM4 in rich medium (RM) using yeast extract from OXOID company (RMOXOID) at different temperatures of 30,36 , and $40^{\circ} \mathrm{C}$ with extra $5 \mathrm{~g} / \mathrm{L}$ tryptone added. At least two independent experiments were carried out with similar results. Values are the mean of one representative experiment with two or more technical replicates. Error bars represent standard deviations.
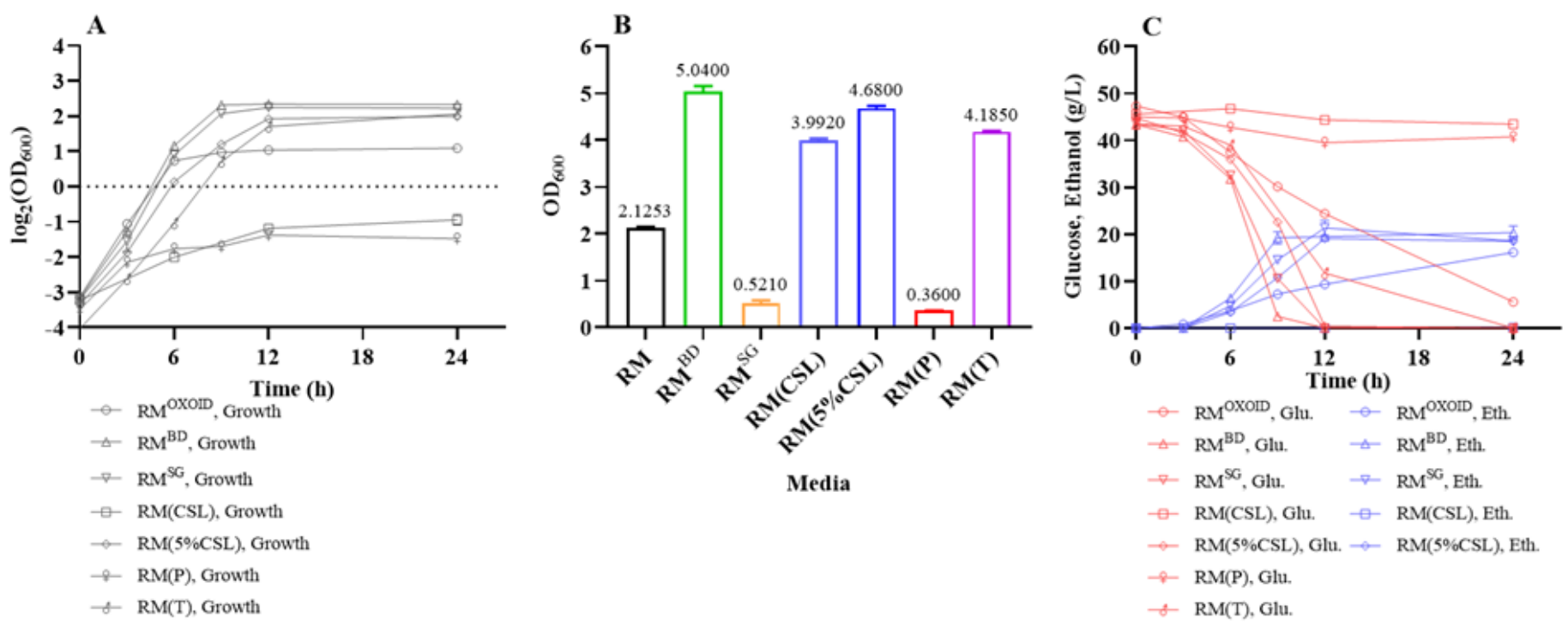
Cell growth (A), final OD600 value (B), as well as glucose (Glu) consumption and ethanol (Eth) production (C) of ZM4 in RM with different nitrogen sources. At least two independent experiments were carried out with similar results. Values are the mean of one representative experiment with two or more technical replicates. Error bars represent standard deviations.
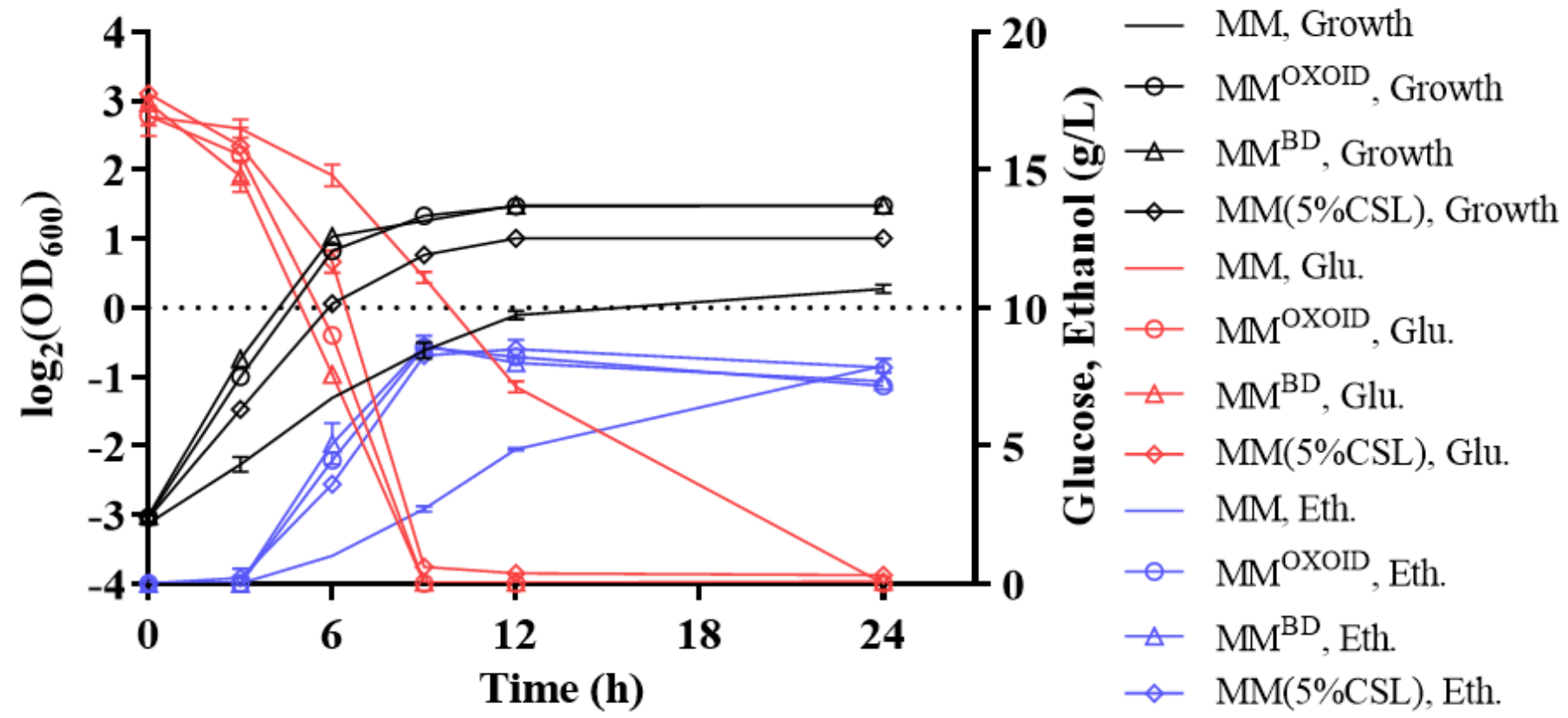

Figure 5

Cell growth, glucose (Glu) consumption and ethanol (Eth) production of ZM4 in MM with different nitrogen sources. At least two independent experiments were carried out with similar results. Values are the mean of one representative experiment with two or more technical replicates. Error bars represent standard deviations.
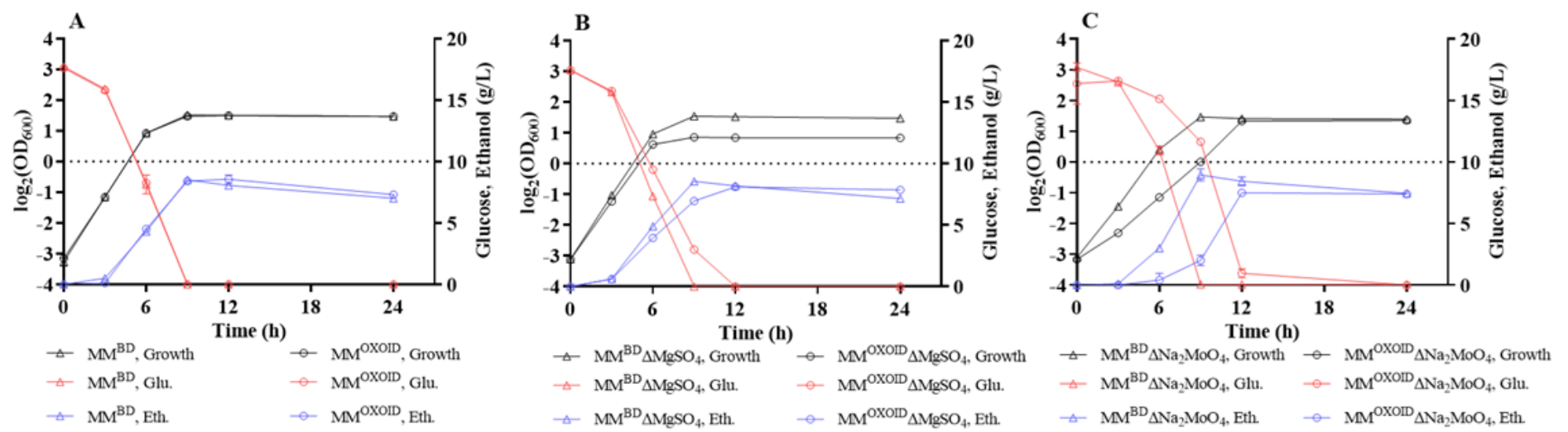

Figure 6 
Cell growth, glucose (Glu) consumption and ethanol (Eth) production of ZM4 in MM with original inorganic nitrogen sources replaced by YEBD and YEOXOID, respectively(A), as well as in above two media with Mg2+ removed (B), or MoO42- removed (C). At least two independent experiments were carried out with similar results. Values are the mean of one representative experiment with two or more technical replicates. Error bars represent standard deviations.
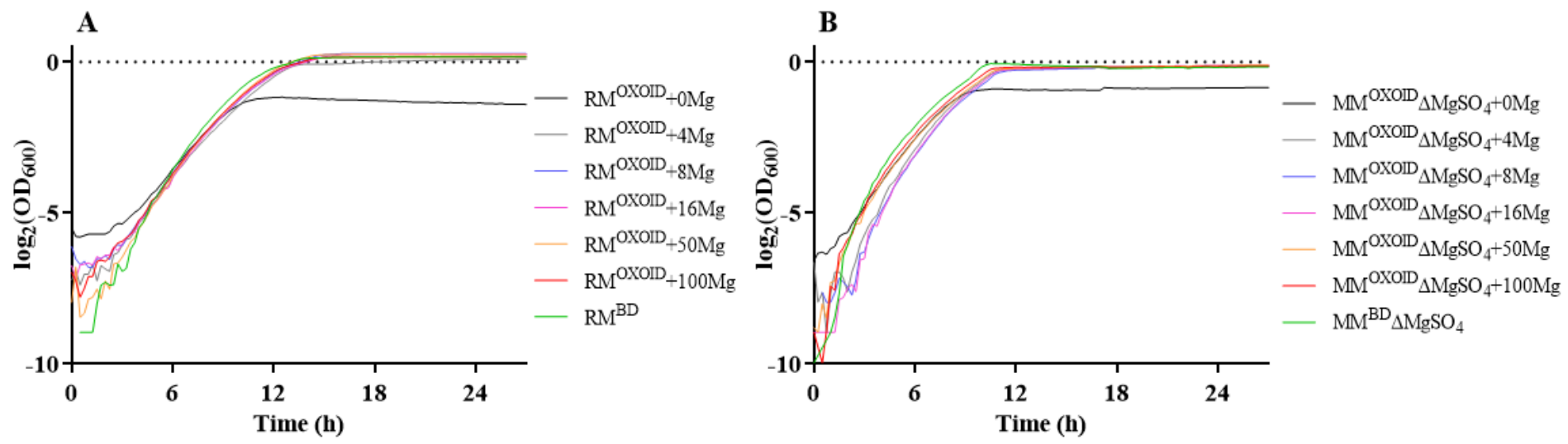

Figure 7

Cell growth of ZM4 in RMOXOID (A) or MMOXOID without MgSO4 (MMOXOID $\triangle$ MgSO4) (B) with Mg2+ supplemented at different concentrations of $0,4,8,16,50$ and $100 \mathrm{mg} / \mathrm{L}$. RMBD and MMBD $\triangle \mathrm{MgSO} 4$ were included as control. At least two independent experiments were carried out with similar results. Values are the mean of one representative experiment with two or more technical replicates. Error bars represent standard deviations.
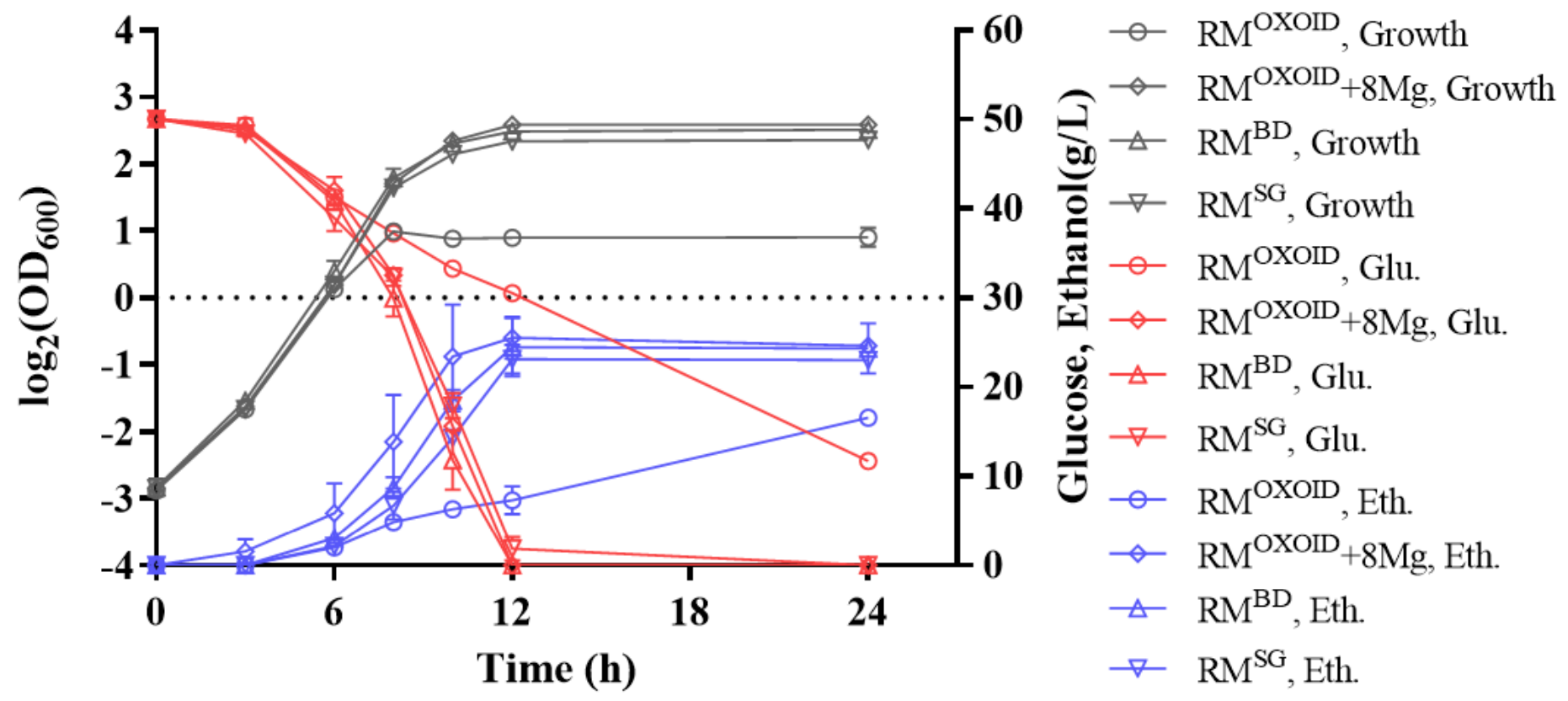

Figure 8 
Cell growth, glucose (Glu) consumption and ethanol (Eth) production of ZM4 in RMOXOID, RMOXOID+8Mg (RMOXOID with $8 \mathrm{mg} / \mathrm{L} \mathrm{Mg2+} \mathrm{added),} \mathrm{RMBD,} \mathrm{and} \mathrm{RMSG.} \mathrm{At} \mathrm{least} \mathrm{two} \mathrm{independent}$ experiments were carried out with similar results. Values are the mean of one representative experiment with two or more technical replicates. Error bars represent standard deviations.
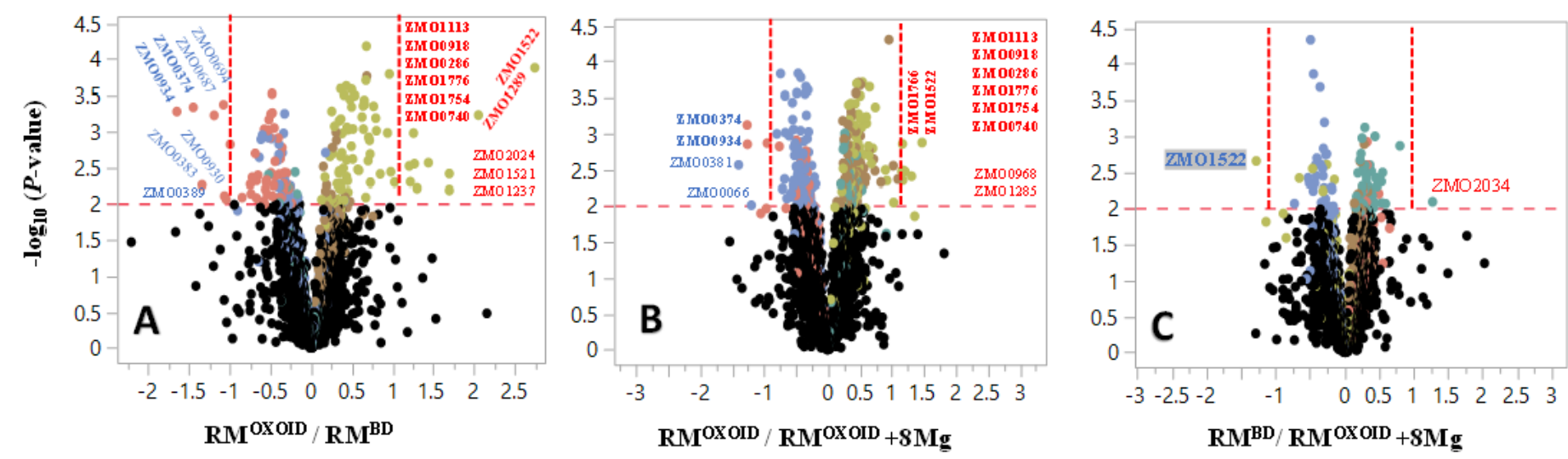

Figure 9

Volcano plots of significantly differentially expressed genes of Z. mobilis cultured in RMOXOID and RMBD (RMOXOID/RMBD, A), RMOXOID and RMOXOID+8Mg (RMOXOID/RMOXOID+8Mg, B), as well as RMBD and RMOXOID+8Mg (RMBD/RMOXOID+8Mg, C). RMOXOID+8Mg is RMOXOID with $8 \mathrm{mg} / \mathrm{L} \mathrm{Mg2+}$ added. $\mathrm{X}$-axis is the log2-based ratios between two conditions examined, and $\mathrm{Y}$-axis is the -log10(P-value) of the difference. The dots above the horizontal red dash line indicate genes significantly differentially expressed, and the vertical red dash line indicate genes significantly differentially expressed with ratio greater than 2 (log2-based ratio greater than 1). Gene name with red and blue color font indicates upregulated and down-regulated ones, respectively. Gene name with bold font indicates common ones between different comparisons of RMOXOID/RMBD, RMOXOID/RMOXOID+8Mg, and $\mathrm{RMBD} / \mathrm{RMOXOID+8Mg}$. 